\title{
HUBUNGAN KERASIONALAN PENGGUNAAN ANTIBIOTIK DENGAN PENYAKIT ISPA PADA PASIEN ANAK DI RSUD PALEMBANG BARI TAHUN 2018
}

\author{
Ibrahim Edy Sapada ${ }^{1}$, Putri Ayu Wandari ${ }^{2}$ \\ ${ }^{1}$ Dosen Program Studi S1 Farmasi \\ STIK Siti Khadijah Palembang \\ Email : ib_edys@yahoo.co.id
}

\begin{abstract}
ABSTRAK
Infeksi saluran pernafasan akut (ISPA) merupakan masalah kesehatan utama yang banyak ditemukan dan paling sering terjadi pada anak. Tingginya pravelansi penyakit ISPA serta dampak yang ditimbulkan membawa akibat pada tingginya konsumsi obat bebas dan antibiotik. Penelitian ini bertujuan untuk mengetahui hubungan kerasionalan penggunaan antibiotik dengan jenis ISPA yang meliputi tepat diagnosis, tepat indikasi, tepat pemilihan obat, tepat dosis, tepat cara pemberian, tepat interval waktu pemberian, dan tepat kondisi pasien di instalasi rawat jalan di RSUD Palembang BARI tahun 2018. Penelitian ini dilakukan dengan metode non-eksperimental dengan pengambilan data secara retrospektif dengan desain cross-sectional. Sampel penelitian 54 pasien Berdasarkan hasil penelitian diketahui terdapat tepat diagnosis sebesar (100\%), tepat indikasi (100\%), tepat pemilihan obat (100\%), tepat dosis $(92,6 \%)$, tepat cara pemberian $(100 \%)$, tepat interval waktu pemberian $(96,3 \%)$, dan tepat kondisi pasien $(100 \%)$, serta diperoleh nilai $p$ value $0,317(p=>0,05)$ maka tidak terdapat hubungan yang bermakna antara kerasionalan penggunaan antibiotik dengan jenis ISPA pada anak di RSUD Palembang BARI tahun 2018.
\end{abstract}

Kata kunci : ISPA, antibiotik, Rasional

\begin{abstract}
Acute respiratory infections is a major health problem that is found and most often occurs in children. The high prevalence of ARI and its effects have an impact on the high consumption of over-the-counter medicines and antibiotics. This study aims to determine the rational relationship between the use of antibiotics and the type of ARI that includes the right diagnosis, the right indication, the right choice of drug, the right dose, the right method of administration, the right time interval for administration, and the condition of the patient in the outpatient installation at Palembang BARI Hospital in 2018. This research was conducted with a non-experimental method with retrospective data collection with cross-sectional design. The sample of this study was 54 patients Based on the results of the study, it is known that there is an exact diagnosis of $(100 \%)$, an exact indication (100\%), the right drug selection $(100 \%)$, the right dose $(92.6 \%)$, the right way of administration $(100 \%)$, the right time interval of administration (96.3\%), and the exact condition of the patient (100\%), and $p$ value of 0.317 ( $\mathrm{p}=>0.05$ ), there is no significant relation between the rational use of antibiotics with the type of acute respiratory infections in children in Palembang BARI Hospital in 2018.
\end{abstract}




\section{PENDAHULUAN}

ISPA (Infeksi Saluran Pernafasan Akut) merupakan penyakit infeksi akut yang menyerang salah satu bagian atau lebih dari saluran nafas mulai dari hidung (saluran atas) hingga alveoli (saluran bawah) termasuk jaringan adneksanya seperti sinus, rongga telinga tengah dan pleura (Irianto, 2014). ISPA disebabkan oleh bakteri dan virus. Terapi yang biasanya diperoleh adalah antibiotik. Penggunaan antibiotik yang tepat dibutuhkan untuk mengatasi masalah resistensi antibiotik yang memang sudah banyak dan mendunia (Syed, et. al, 2013).

Penggunaan antibiotik yang terkendali dapat mencegah munculnya resistensi dan menghemat penggunaan antibiotik yang pada akhirnya akan mengurangi beban biaya perawatan pasien, mempersingkat lama perawatan serta meningkatkan kualitas pelayanan rumah sakit maupun puskesmas (Kemenkes RI, 2011). Penggunaan antibiotik yang begitu luas dan lama menyebabkan organisme infeksius telah mampu beradaptasi dengan antibiotik, hal ini menyebabkan efektivitas dari antibiotik itu berkurang dan terjadi resistensi antibiotik (CDC, 2011).

Angka kejadian ISPA termasuk pneumonia yang masih tinggi pada balita dan anak-anak disebabkan frekuensi penggunaan antibiotik yang tidak rasional. Penggunaan antibiotik pada infeksi saluran pernafasan akut, khususnya pada pasien usia dibawah lima tahun yang merupakan penderita terbesar dari penyakit ISPA perlu mendapatkan perhatian khusus (Sugiarti, 2015). Menurut penelitian Harahap (2017), menunjukkan bahwa golongan antibiotik yang sering diresepkan adalah golongan penisilin yaitu amoksisilin (30\%). Evaluasi penggunaan antibiotik yang rasional berdasarkan pedoman Kemenkes RI 2011 meliputi kriteria tepat obat $(100 \%)$, tepat pasien $(100 \%)$, tepat indikasi $(100 \%)$, tepat dosis antibiotik $(91,32 \%)$, tepat frekuensi pemberian antibiotik (95,62\%), dan tepat durasi $(97,1 \%)$. Penggunaan antibiotik pada pasien ISPA anak masih ada yang belum rasional. Ketepatan penggunaan antibiotik perlu diperhatikan, agar tercapai pengobatan yang rasional dan tidak terjadi resistensi. Tujuan penelitian ini adalah untuk mengetahui hubungan kerasionalan penggunaan antibiotik dengan jenis ISPA pada pasien anak di RSUD Palembang BARI Tahun 2018.

\section{METODE PENELITIAN}

Jenis penelitian ini menggunakan metode observasi dengan design penelitian cross-sectional. Pengambilan data dilakukan secara retrospektif yaitu dengan mencatat data pasien yang terdapat pada rekam medik. Waktu penelitian selama 1 bulan di Poliklinik rawat jalan RSUD Palembang BARI. Sampel dalam penelitian ini adalah sebagian pasien anak yang terdiagnosis ISPA yang memenuhi kriteria inklusi dan ekslusi. Cara pengambilan sampel adalah dengan metode simple random sampling.

\section{HASIL DAN PEMBAHASAN}

\section{A. Analisis Univariat}

Analisis ini digunakan untuk mengetahui gambaran setiap variabel dalam bentuk distribusi frekuensi dari variabel kerasionalan penggunaan antibiotik dan jenis ISPA pada anak di RSUD Palembang BARI tahun 2018, didapatkan hasil :

\section{Distribusi Kerasionalan penggunaan antibiotik pada anak di instalasi rawat jalan RSUD Palembang BARI tahun 2018.}

Dalam penelitian ini penggunaan antibiotik yang rasional dinilai dengan aspek ketepatan diagnosis, ketepatan indikasi, ketepatan pemilihan obat, ketepatan dosis, ketepatan cara pemberian, ketepatan interval waktu pemberian, dan ketepatan kondisi pasien. Pasien dikatakan mendapat terapi antibiotik secara rasional bila memenuhi evaluasi ketujuh penilaian ketepatan. Jika terdapat salah satu diantara ketujuh ketepatan tidak tepat, maka pasien tidak dapat memenuhi evaluasi ketepatan dan dikatakan bahwa penggunaan antibiotik tidak rasional. 
Tabel 1. Distribusi Frekuensi Analisis Ketepatan Antibiotik pada Pasien Anak di IInstalasi Rawat Jalan RSUD Palembang BARI tahun 2018

\begin{tabular}{|c|c|c|c|}
\hline Ketepatan & Kriteria & Jumlah & Persentase \\
\hline \multirow[t]{2}{*}{ Ketepatan Diagnosis } & Tepat & 54 & 100 \\
\hline & Tidak Tepat & 0 & 0 \\
\hline \multirow[t]{2}{*}{ Ketepatan Indikasi } & Tepat & 54 & 100 \\
\hline & Tidak Tepat & 0 & 0 \\
\hline \multirow[t]{2}{*}{ Ketepatan Pemilihan Obat } & Tepat & 54 & 100 \\
\hline & Tidak Tepat & 0 & 0 \\
\hline \multirow[t]{2}{*}{ Ketepatan Dosis } & Tepat & 50 & 92,6 \\
\hline & Tidak Tepat & 4 & 7,4 \\
\hline \multirow[t]{2}{*}{ Ketepatan Cara Pemberian } & Tepat & 54 & 100 \\
\hline & Tidak Tepat & 0 & 0 \\
\hline \multirow{2}{*}{$\begin{array}{lll}\text { Ketepatan } & \text { Interval } & \text { Waktu } \\
\text { Pemberian } & & \end{array}$} & Tepat & 52 & 96,3 \\
\hline & Tidak Tepat & 2 & 3,7 \\
\hline \multirow[t]{2}{*}{ Ketepatan Kondisi Pasien } & Tepat & 54 & 100 \\
\hline & Tidak Tepat & 0 & 0 \\
\hline
\end{tabular}

Tabel 2. Distribusi Frekuensi Kerasionalan Penggunaan Antibiotik pada anak di RSUD Palembang BARI tahun 2018

\begin{tabular}{lll}
\hline Kerasionalan & Jumlah & \% \\
\hline Ya,Rasional & 48 & 88,9 \\
Tidak Rasional & 6 & 11.1 \\
\hline Jumlah & $\mathbf{5 4}$ & $\mathbf{1 0 0}$ \\
\hline
\end{tabular}

Dari Tabel 2 di atas dapat diketahui bahwa dari 54 responden, penggunaan antibiotik yang rasional berjumlah 48 responden $(88,9 \%)$ lebih banyak dibandingkan pengunaan tidak rasional berjumlah 6 responden $(11,1 \%)$.

Tabel 3. Distribusi Frekuensi Jenis ISPA pada Pasien Anak di instalasi rawat jalan RSUD Palembang BARI tahun 2018

\begin{tabular}{lll}
\hline Terdiagnosa ISPA & Jumlah & $\%$ \\
\hline ISPA Atas & 41 & 76.0 \\
ISPA Bawah & 13 & 24.0 \\
\hline Jumlah & 54 & 100 \\
\hline
\end{tabular}

Dari Tabel 3 di atas dapat diketahui bahwa dari 54 responden, pasien yang terdiagnosa ISPA Atas adalah sebanyak 41 orang $(76 \%)$ lebih banyak dibandingkan dengan yang terdiagnosa ISPA Bawah sebanyak 13 orang (24\%).

\section{B. Analisa Bivariat}

Tabel 4. Hubungan antara Jenis ISPA dengan Kerasionalan Pengunaan Antubiotika Distribusi pada Pasien Anak di instalasi rawat jalan RSUD Palembang BARI tahun 2018

\begin{tabular}{lllllll}
\hline \multirow{2}{*}{ Jenis } & \multicolumn{4}{c}{ Kerasionalan } & \multicolumn{2}{c}{ Total } \\
\cline { 2 - 6 } & \multicolumn{2}{c}{ Ya } & \multicolumn{2}{c}{ Tidak } & n & \% \\
\cline { 2 - 5 } & $\mathbf{n}$ & $\mathbf{\%}$ & $\mathbf{n}$ & $\mathbf{\%}$ & & \\
\hline ISPA & 35 & 85.4 & 6 & 14.6 & 41 & 100 \\
Atas & & & & & & \\
\hline ISPA & 13 & 100 & 0 & 0 & 13 & 100 \\
Bawah & & & & & & \\
\hline Jumlah & $\mathbf{4 8}$ & $\mathbf{8 8 . 9}$ & $\mathbf{6}$ & $\mathbf{1 1 . 1}$ & $\mathbf{5 4}$ & $\mathbf{1 0 0}$ \\
\hline P value $: 0,317$ & & & & &
\end{tabular}

Dari Tabel 4. diatas dapat diketahui bahwa pasien anak yang terdiagnosa ISPA Atas dan diberikan antibiotika yang rasional adalah sebesar 35 pasien (85.4\%). Sedangkan pasien anak yang terdiagnosa ISPA Bawah dan diberikan antibiotika yang rasional adalah sebesar 13 pasien (100\%). Dari hasil uji alternative Fisher diperoleh nili $\mathrm{p}=0.317$, Ho 
gagal ditolak, yang artinya tidak ada hubungan antara kerasionalan mengunakan antibiotika dengan jenis penyakit ISPA.

\section{PEMBAHASAN}

\section{Hubungan antara Jenis ISPA dengan Kerasionalan Penggunaan Antubiotika.}

Dari anlisis data diketahui bahwa tidak ada hubungan yang bermakna antara jenis ISPA dengan kerasionalan penggunnan antibiotika. Hasil penelitian ini sejalan dengan peneltian Harahap (2017) yang mengemukakan tidak ada hungan antara Jenis Penyakit dengan kerasionalan menggunakan antibiotika.

Pada dasarnya kerasionalan penggunaan obat merupakan hal yang penting dalam meningkatkan pelayanan kepada pasien. Menurut WHO obat secara tepat atau rasional apabila pasien menerima obat sesuai dengan kondisi klinisnya, dengan dosis yang berada dalam range terapi, dalam periode waktu yang sesuai dan dengan biaya yang terjangkau oleh dirinya dan kebanyakan masyarakat Dalam penelitian ini penggunaan antibiotik yang rasional dinilai dengan aspek ketepatan diagnosis, ketepatan indikasi, ketepatan pemilihan obat, ketepatan dosis, ketepatan cara pemberian, ketepatan interval waktu pemberian, dan ketepatan kondisi pasien.

1. Tepat Diagnosis

Penilaian ketepatan indikasi ini hanya dilakukan berdasarkan diagnosa yang ditegakkan oleh dokter. Seluruh pasien anak dengan diagnosa ISPA memperoleh antibiotik yang sudah sesuai dengan pedoman pengobatan sehingga dikategorikan sebagai tepat indikasi. Setelah melihat diagnosis dan pemberian antibiotik yang diresepkan, peneliti mendapatkan hasil ketepatan indikasi sebesar (100\%), analisa data menunjukkan bahwa pemberian antibiotik tepat karena adanya bukti infeksi berupa demam dan telah berlangsung selama beberapa hari.

\section{Tepat Pemilihan Obat}

Penilaian ketepatan pemilihan obat dilakukan dengan membandingkan buku acuan standar "Pharmaceutical Care dengan pada pasien. Obat harus memiliki efek terapi
Aspek ketepatan diagnosis ini dinilai dengan melihat pada gejala klinis pasien dan pemeriksaan secara fisik. Analisa data pada penelitian ini mengacu pada standar terapi 'Buku Ajar Respirologi Anak', IDAI Tahun 2015 dan "Pharmaceutical Care untuk Penyakit Infeksi Saluran Pernafasan', (Depkes RI, 2005) untuk menentukan kesesuaian terapi pada pasien.

Pada penelitian ini gejala faringritis yang sesuai dengan IDAI (2015) berupa demam, nyeri tenggorokan, batuk, mual muntah dan sakit kepala. Gejala otitis media yang sesuai IDAI (2015) yang dialami pasien pada penelitian ini berupa adanya cairan di rongga telinga bagian tengah, demam, nyeri, hilangnya pendengaran, dan pilek. Sedangkan gejala bronkitis yang sesuai Depkes RI (2005) dapat berupa batuk yang menetap, sesak nafas, lemah, lesu, nyeri kepala, dan demam.

Setelah melihat gejala dan diagnosis yang diberikan, maka penilaian aspek ketepatan diagnosis ini telah tepat seluruhnya $(100 \%)$.

\section{Tepat Indikasi}

Ketepatan indikasi dilakukan dengan membandingkan diagnosa penyakit dan antibiotik yang diberikan dengan buku acuan standar "Pharmaceutical Care untuk Penyakit Infeksi Saluran Pernafasan", (Depkes RI, 2005). Didalam catatan rekam medik terkadang dokter tidak menulis alasan pemberian anti biotik yang diresepkan

sesuai dengan spektrum penyakit. Pada hasil analisis data terlihat bahwa sudah tepat $100 \%$ sesuai dengan buku acuan standar.

4. Tepat Dosis

Penilaian ketepatan dosis disesuaikan dengan panduan literatur yang berlaku yaitu "'Drug Information Handbook" (2009). Dosis antibiotik tersebut dihitung sesuai dengan perhitungan dosis berdasarkan berat badan setiap anak dikali dengan dosis yang ditentukan dalam buku pedoman dan didapatkan hasil yaitu tepat dosis sebanyak $(92,6 \%)$ dan tidak tepat dosis sebanyak $(7,4 \%)$. Ketidaktepatan dosis terjadi pada antibiotik cefadroxyl dan amoksisilin hal ini disebabkan karena kurangnya dosis. Kurangnya dosis terdapat pada nomor pasien (9 dan 10) dimana dosis cefadroxyl yang 
diberikan kurang sehingga tidak masuk kedalam range terapi sesuai dosis acuan. Dan juga pada nomor pasien (16 dan 20) didapatkan dosis amoksisilin yang diberikan juga kurang sehingga tidak berada di dalam range terapi. Pemberian dosis yang tidak tepat ataupun tidak sesuai dapat menyebabkan berkurangnya efektifitas penggunaan obat dan bahkan dapat membahayakan pasien. Dosis obat jika diberikan terlalu kecil maka pengobatan tidak akan efektif. Pengobatan menjadi tidak efektif karena efek dari obat terlalu rendah atau bahkan tidak muncul.

\section{Tepat Cara Pemberian}

Penilaian ketepatan cara pemberian antibiotik dilakukan dengan membandingkan cara penggunaan dengan kondisi pasien. Hasil penelitian diperoleh $(100 \%)$ obat tepat cara pemberian dan bentuk sediaan dengan asumsi pasien dapat menerima obat secara oral. Ketika penggunaan obat secara oral masih mungkin pada pasien, maka sebaiknya dihindari pemberian obat secara parenteral.

Hal ini sesuai dalam penggunaan obat berdasarkan umur, dimana kebanyakan anakanak lebih menyukai obat dalam bentuk sediaan sirup yang lebih mudah ditelan dibandingkan dengan sediaan padat lainnya secara oral dan dosisnya mudah diatur (Jas, 2007).

6. Tepat Interval Waktu Pemberian

Penilaian ketepatan interval waktu pemberian disesuaikan dengan panduan literatur yang berlaku yaitu 'Drug Information Handbook"' (2009). Berdasarkan hasil penelitian, didapatkan hasil yaitu tepat interval $(96,3 \%)$ dan tidak tepat sebanyak $(3,7 \%)$. Ketidaktepatan frekuensi pemberian antibiotik dikarenakan pada beberapa pasien yang diresepkan antibiotik amoksisilin diberikan 2x1 (tiap 12 jam). Padahal berdasarkan buku standar acuan Drug Information Handbook (2009), bahwa Amoksisilin diberikan 3 x sehari (tiap 8 jam). Jika frekuensi pemberian antibiotik yang diberikan kurang dari yang ada pada ketentuan dalam buku standar acuan maka akan menyebabkan kurang efektifnya terapi yang diberikan.

Masing-masing obat memiliki kandungan yang berbeda-beda. Hal tersebut mempengaruhi kandungan obat dalam tubuh sehingga aturan penggunaannya pun berbedabeda contohnya yaitu Amoksisilin yang hanya mampu bertahan dalam tubuh sampai 8 jam saja, sehingga pasien harus mengkonsumsi kembali agar memberikan hasil yang maksimal. Karena dalam sehari yaitu 24 jam, sehingga diperlukan 3 kali dosis pemberian Amoksisilin. Berbeda dengan obat lainnya yang mampu bertahan dalam tubuh hingga 12 jam atau bahkan 24 jam dalam tubuh, sehingga dosis yang diperlukan hanya 2 kali sehari atau hanya 1 kali sehari.

\section{Tepat Kondisi Pasien}

Aspek penilaian ketepatan kondisi pasien dinilai dengan kesesuaian pemberian antibiotik kepada pasien dengan keadaan dan kondisi klinis serta ada atau tidak adanya kontraindikasi pada pasien. Pada penelitian ini didapatkan hasil tepat kondisi pasien tepat (100\%). Berdasarkan data rekam medik pasien ISPA di RSUD Palembang BARI tahun 2018 diketahui pasien tidak memiliki riwayat alergi terhadap antibiotik yang diresepkan, sehingga obat tersebut aman digunakan. Pemberian antibiotik yang diberikan pada pasien ISPA anak di rawat jalan RSUD Palembang BARI adalah Amoksisilin, Eritromisin, Azitromisin, Cefadroxyl dan Cefixime sudah memenuhi kriteria tepat kondisi pasien karena tidak ada kontraindikasi kondisi pasien. Dimana Amoksisilin, Eritromisin, Azitromisin, Cefadroxyl dan Cefixime dikontraindikasikan terhadap pasien yang hipersensitif terhadap obat tersebut. Selain itu juga tidak ada kontraindikasi dengan umur pasien.

Setelah data aspek ketepatan diagnosis, ketepatan indikasi, ketepatan pemilihan obat, ketepatan dosis, ketepatan cara pemberian, ketepatan interval waktu pemberian, dan ketepatan kondisi pasien disesuaikan dengan panduan yang digunakan untuk menentukan kerasionalan penggunaan antibiotik pada masing-masing pasien. Data yang diperoleh menunjukkan bahwa pada 48 responden $(88,9 \%)$ mendapatkan antibiotik yang rasional dan 6 responden $(11,1 \%)$ mendapatkan antibiotik yang tidak rasional. Dari hasil penelitian ini masih ditemukan penggunaan antibiotik yang tidak rasional, dikarenakan masih terdapat kesalahan dalam peresepan 
obat sehingga apoteker harus lebih mengawasi dan mempromosikan penggunaan

Sehingga pengunaan antibiotika yang tidak rasional dapat dihindari.

\section{KESIMPULAN DAN SARAN}

Berdasarkan hasil analisis pembahasan maka dapt disimpukan bahwa pasien anak yang terdiagnosa ISPA Atas dan diberikan antibiotika yang rasional adalah sebesar 35 pasien $(85.4 \%)$. Sedangkan pasien anak yang terdiagnos ISPA Bawah dan diberikan antibiotika yang rasional adalah sebesar 13 pasien (100\%). Dari hasil uji alternative Fisher diperoleh nili $p=0,317$, tidak ada hubungan antara kerasionalan mengunakan antibiotika dengan jenis penyakit ISPA. Disarankan untuk dilakukan penelitian lebih lanjut dengan jumlah sampel yang lebih banyak.

\section{DAFTAR PUSTAKA}

Aberg,.J.A., $\quad$ Lacy.C.F, Amstrong,I.,I., Goldman, M.P, and Lance, I.,I., 2009. Drug Information Handbook, 17th edition. Lexicomp for the American Pharmacist Association.

Centers for Disease Control and Prevention, (CDC) 2011. Terdapat di:http://www.cdc.gov/getsmart/antibiotic -use/fast-facts.html Diakses pada tanggal : 12 Desember 2018.

Depkes RI. 2005. Pharmaceutical Care Untuk Penyakit Infeksi Saluran Pernafasan. Jakarta : Indonesia.

Irianto K. 2014. Epidemiologi Penyakit Menular Dan Tidak Menular Panduan Klinis. Bandung: Alfabeta.

Kemenkes RI. 2011. Modul Penggunaan Obat Rasional, Kementerian Kesehatan Republik Indonesia, Jakarta.

Notoadmojo. 2014. Metodologi Penelitian Kesehatan Edisi Revisi. Jakarta: Rineka Cipta antibiotik yang rasional baik kepada tenaga profesional, pasien maupun masyarakat.

Sugiarti T. 2015. Studi Penggunaan Antibiotik pada Pasien ISPA Usia Bawah Lima Tahun. Jawa Timur: Fakultas Farmasi Universitas Jember 